\title{
Outbreaks of Bacterial Spot Caused by Xanthomonas gardneri on Processing Tomato in Central-West Brazil
}

\author{
Alice M. Quezado-Duval, Empresa Brasileira de Pesquisa Agropecuária-Centro Nacional de Pesquisa de Hortaliças, \\ Caixa Postal 218, CEP-70359-970, Brasília-DF, Brazil; Rui P. Leite, Jr., Instituto Agronômico do Paraná, Caixa \\ Postal 481, CEP-86001-970, Londrina, PR, Brazil; and Daniela Truffi and Luis E. A. Camargo, Universidade de \\ São Paulo-Escola Superior de Agricultura "Luiz de Queiroz”, Caixa Postal 09, CEP-13418-900, Piracicaba, SP, Brazil
}

\begin{abstract}
Quezado-Duval, A. M., Leite, R. P., Jr., Truffi, D., and Camargo, L. E. A. 2004. Outbreaks of bacterial spot caused by Xanthomonas gardneri on processing tomato in central-west Brazil. Plant Dis. 88:157-161.

Severe epidemics of bacterial spot have been observed in central-west Brazil in fields of processing tomato. Several xanthomonads, Xanthomonas axonopodis pv. vesicatoria, X. vesicatoria, or X. gardneri, can cause the disease; therefore, attempts were made to identify the pathogen species present in this region. A total of 215 strains were obtained from 10 commercial areas in 1997, 1998, and 2000. The strains were characterized using pulsed-field gel electrophoresis (PFGE) and by their amylolytic and pectolytic activities. Representative strains from each PFGE haplotype then were tested for pathogenicity on tomato and pepper, carbon source utilization, and whole protein sodium dodecyl sulfate-polyacrylamide gel electrophoresis. rRNA sequence comparisons also were performed. All strains recovered from six fields were classified as $X$. gardneri, whereas $X$. vesicatoria and $X$. axonopodis pv. vesicatoria also were detected in the remaining four fields. Strains of $X$. gardneri, which could be grouped into two PFGE haplotypes, were unable to hydrolyze starch and pectate and to utilize gentiobiose and maltose. They expressed the $\beta$ protein of $27 \mathrm{kDa}$ and were pathogenic on tomato but variable on pepper. This is the first report of outbreaks of bacterial spot on tomato caused by $X$. gardneri.
\end{abstract}

Additional keywords: Lycopersicon esculentum

Processing tomato (Lycopersicon esculentum Mill.) production areas in Brazil gradually are moving from the southeastern and northeastern regions towards the central-west, in the states of Goiás and Minas Gerais $(1,24)$. In this new agricultural frontier, production increased from 5,000 ha in 1991 to 11,000 ha in 1998 and represents one-half of the total Brazilian acreage of processing tomato. Also, the edaphoclimatic conditions are favorable for the crop, resulting in a superior average yield of $63 \mathrm{t} / \mathrm{ha}$ in 1999 compared with the Brazilian average of $46 \mathrm{t} / \mathrm{ha}$ (24).

Bacterial spot, a worldwide important disease of tomato and pepper (Capsicum annuum L.), has become a major problem in sprinkler-irrigated fields of processing tomato in Brazil. The disease has the potential to cause heavy yield losses due to its seedborne nature, the low efficiency of chemical control, and the lack of resistant

Corresponding author: A. M. Quezado-Duval E-mail: alice@cnph.embrapa.br

This work was supported in part by $\mathrm{CNPq}$ grant 146214/99-4 and FAPESP grant 00/09059-8.

Accepted for publication 4 September 2003.

Publication no. D-2003-1125-01R

(C) 2004 The American Phytopathological Society cultivars $(10,11,14)$. Three Xanthomonas spp. have been shown to cause bacterial spot on tomato and pepper: Xanthomonas axonopodis pv. vesicatoria, $X$. vesicatoria, and $X$. gardneri $(15,16,27)$. The latter was first described in Yugoslavia and was initially classified as Pseudomonas gardneri (26). Since then, it had been considered a synonym of $X$. vesicatoria (8). However, the taxonomical status of $X$. gardneri is still undefined (30) in spite of being genetically and phenotypically distinct from $X$. axonopodis pv. vesicatoria and $X$. vesicatoria $(7,12,15,16)$. Thus, we will refer to this unique population as $X$. gardneri for lack of a universally accepted species name.

The criteria used to phenotypically characterize the Xanthomonas spp. associated with bacterial spot on tomato include amylolytic and pectolytic activities, patterns of carbon utilization, serology, fatty acid profiles, silver staining of protein profiles using sodium dodecyl sulfate-polyacrylamide gel electrophoresis (SDS-PAGE), and pathogenicity $(4,15,25)$. Also, their genomic structures have been differentiated by analysis of restriction profiles of $h r p$ genes, pulsed-field electrophoresis (PFGE) of digested genomic DNA, DNA-DNA reassociation kinetics, repetitive DNA sequence-based polymerase chain reaction (rep-PCR), and rRNA sequence homology
$(5,15,18,19) . X$. gardneri belongs to group D of the xanthomonads causing bacterial spot disease on tomato. The bacterium is characterized by its inability to hydrolyze starch and pectate and to utilize gentiobiose as a source of carbon (5), a reaction pattern with a group of monoclonal antibiodies, and the presence of a $27-\mathrm{kDa}$ protein typical of this group (16). In addition to the reference strain, originally described in Yugoslavia in 1957 (26), other $X$. gardneri strains recently were identified in Costa Rica (5).

This work reports the identification and characterization of strains of $X$. gardneri associated with severe outbreaks of bacterial spot in commercial fields of processing tomato in the central-west region of Brazil.

\section{MATERIALS AND METHODS}

Isolation of strains. Strains were isolated from diseased plants, most of them hybrid cultivars, grown in sprinkler-irrigated fields from the states of Goiás and Minas Gerais (Table 1). Leaves and fruit showing symptoms of bacterial spot were collected randomly throughout the fields.

Plant material was washed in tap water and pieces containing typical spot lesions were excised, surface disinfested with $70 \%$ ethanol for $10 \mathrm{~s}$ and with $3 \%$ sodium hypochloride for $30 \mathrm{~s}$, and finally rinsed with sterile distilled water. Bacteria were isolated by grinding the tissue in sterile distilled water $(100 \mu \mathrm{l})$ with a pestle in a sterile mortar and streaking the undiluted extract onto nutrient agar (NA) plates (23). The plates were incubated at $28^{\circ} \mathrm{C}$ for 3 to 5 days. Single, yellow colonies were selected and transferred to another NA plate to secure purity. The strains were stored in phosphate buffer ( $\mathrm{pH}$ 7.0) at room temperature over the short term and in nutrient broth amended with $30 \%$ glycerol at $-80^{\circ} \mathrm{C}$ for long-term storage (21). Strains 75-3, XV56 (4), and XG101 (26) were included in the study as representatives of $X$. axonopodis pv. vesicatoria, $X$. vesicatoria, and $X$. gardneri, respectively. These strains were obtained from the working collection of Instituto Agronômico do Paraná, Londrina, Brazil.

PFGE of digested genomic DNA. PFGE analysis was performed with all 215 field strains as described by Egel et al. (9), with minor modifications. Genomic DNA from lysed agar-embedded cells of bacte- 
rial strains was digested with $\mathrm{XbaI}$ (Invitrogen Life Technologies, Carlsbad, CA). DNA fragments were resolved in running buffer ( $45 \mathrm{mM}$ Tris- $\mathrm{HCl}, 45 \mathrm{mM}$ boric acid, 1 mM EDTA, pH 8.0). Runnings were carried out in a CHEF-DR II apparatus (Bio-Rad Laboratories, Hercu$1.2 \%$ agarose gels prepared with $0.5 \times \mathrm{TBE}$

les, CA) at $12^{\circ} \mathrm{C}$ and $6 \mathrm{~V} / \mathrm{cm}$ of gel with pulse times of $4 \mathrm{~s}$ for $1 \mathrm{~h}$ followed by $15 \mathrm{~s}$ for $24 \mathrm{~h}$. Gels were stained with ethidium bromide $(0.5 \mu \mathrm{g} / \mathrm{ml})$. Co-migrating DNA fragments larger than $100 \mathrm{~kb}$ (9) were compared and distinct banding patterns were regarded as different haplotypes. Dice coefficients of similarity were calcu-

Table 1. Number of strains of Xanthomonas species isolated from processing tomato plants with bacterial spot in the central-west region of Brazil

\begin{tabular}{|c|c|c|}
\hline $\begin{array}{l}\text { State, county and year, } \\
\text { field number }\end{array}$ & Tomato cultivars ${ }^{a}$ & $\begin{array}{c}\text { Number of } \\
\text { strains }\end{array}$ \\
\hline \multicolumn{3}{|l|}{ Goiás } \\
\hline \multicolumn{3}{|l|}{ Itapaci, 1997} \\
\hline 1 & $\mathrm{CNPH} 401-8$ & 9 \\
\hline 2 & Andino & 10 \\
\hline 3 & Topmech & 4 \\
\hline \multicolumn{3}{|l|}{ Rio Verde, 1997} \\
\hline 1 & $\begin{array}{l}\text { Mixture of hybrids of APTX and Heinz series, } \\
\text { Agroceres } 7022 \text { and Andino }\end{array}$ & 44 \\
\hline 2 & Santa Adelia & 3 \\
\hline \multicolumn{3}{|l|}{ Morrinhos, 1998} \\
\hline 1 & Hypeel 108, Hypeel 45 & 39 \\
\hline $2^{b}$ & Hypeel 45 & 6 \\
\hline 2 & Hypeel 45, Rio Grande & 20 \\
\hline 3 & Petomech & 4 \\
\hline \multicolumn{3}{|l|}{ Morrinhos, 2000} \\
\hline 1 & RPT 1570, Hypeel 108, Petoseed 6914 & 65 \\
\hline \multicolumn{3}{|l|}{ Minas Gerais } \\
\hline \multicolumn{3}{|l|}{ Patos de Minas, 1998} \\
\hline 1 & Viradoro, Ragu 9414, Heinz 9498 & 11 \\
\hline
\end{tabular}

a Rio Grande, Topmech, Petomech, CNPH 401-8, and Viradoro are open-pollinated cultivars, whereas the others are hybrids.

b Samples collected at seedling stage.

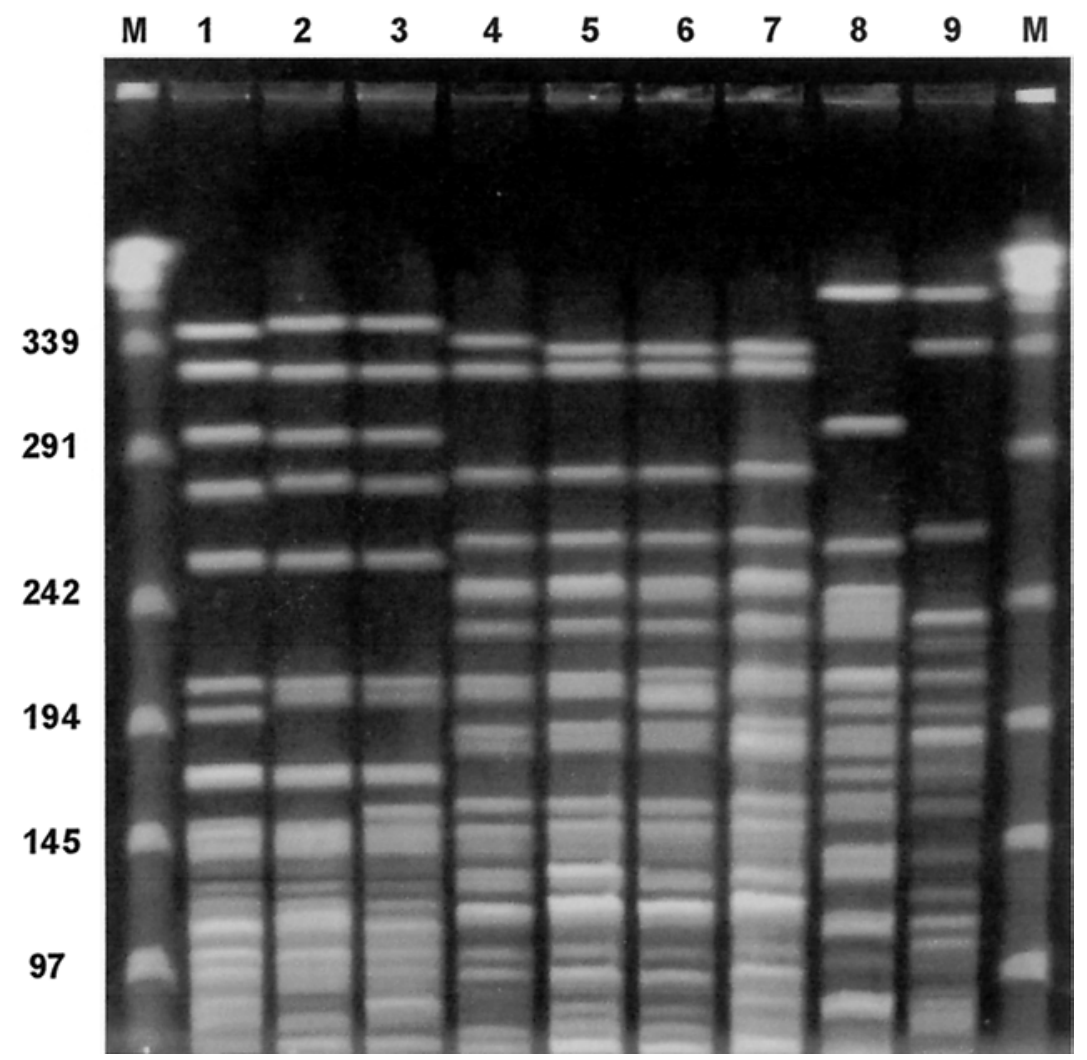

Fig. 1. XbaI-pulsed-field gel electrophoresis (PFGE) patterns of strains of Xanthomonas spp. Lane M, molecular weight marker $\lambda$ DNA-PFGE (New England Biolabs, Beverly, MA). Lanes 1 to 9, strain XG101, CNPH467, CNPH496, 75-3, CNPH411, CNPH468, CNPH485, XV56, and CNPH345. Molecular sizes are given in kilobases. lated from the restriction fragment data for all pairwise strain combinations, including strains 75-3, XV56, and XG101 (PFGE groups A, B, and D, respectively [16]), with NTSYS-pc (version 1.70; Exeter Software, Setaukaat, NY). Parsimony analysis was used to establish genetic relationships among representative strains from each haplotype, including strains 753, XV56, and XG101. Analyses of 500 bootstrap replicates were performed using the PARS routine of PHYLIP version $3.6 \mathrm{a} 3$ (10) and a consensus tree was generated using the CONSENSE routine.

Starch hydrolysis and pectate utilization. The ability to hydrolyze starch and pectate was determined by placing $10-\mu \mathrm{l}$ droplets of bacterial suspensions $\left(10^{8}\right.$ $\mathrm{CFU} / \mathrm{ml}$, absorbance at $600 \mathrm{~nm}\left[A_{600}\right]=$ $0.1)$ prepared in distilled water on NA amended with $1 \%$ starch and on crystal violet-pectate medium without crystal violet (6). All 215 field strains were used in these tests. A strain was considered positive for amylolytic activity if the bacterial growth was surrounded by a clear zone after flooding the plates with lugol. A depression in the medium was interpreted as a positive reaction for pectolytic activity. Strain XV56 was used as positive control and strains 75-3 and XG101 as negative controls for both tests.

Pathogenicity tests. The susceptible cultivars Walter (tomato) and Early Calwonder (pepper) were inoculated with 94 strains which included the PFGE haplotypes and representative strains from each field. Bacterial cultures were obtained from colonies transferred from NA to nutrient broth and shaken (12,000 rpm) overnight at $28^{\circ} \mathrm{C}$. Bacterial suspensions then were centrifuged and the resulting pellets were resuspended in distilled water to a final concentration of $5 \times 10^{7} \mathrm{CFU} / \mathrm{ml}$ (1:10 dilution of $A_{600}=0.3$ ). Plants with four to five true leaves ( 6 and 5 weeks after sowing for pepper and tomato plants, respectively) were spray inoculated with bacterial suspension and then maintained in a moist chamber for 2 days before being transferred to a greenhouse $\left(25\right.$ to $\left.35^{\circ} \mathrm{C}\right)$. Two plants of each cultivar were used for each strain. Symptom development was observed periodically up to 21 days after inoculation.

Carbon source utilization. The carbon sources tested were gentiobiose, maltose, $\mathrm{D}(+)$ melezitose, $\mathrm{D}(+)$ raffinose, and $\mathrm{D}(+)$ trehalose $(5,8)$. Bacterial suspensions $(10$ $\mu \mathrm{l}$ each) prepared with distilled sterile water $\left(10^{8} \mathrm{CFU} / \mathrm{ml}, A_{600}=0.1\right)$ were deposited on plates of medium $C$ of Dye (13) amended with $0.5 \%$ of one of the carbon sources (24). Bacterial growth was compared with plates devoid of carbon after incubation for up to 5 days at $28^{\circ} \mathrm{C}$. Two plates were used per strain. The test was performed with 21 strains representing the PFGE haplotypes and strains 75-3, XV56, and XG101. 
Electrophoresis of soluble proteins. Twenty-one strains and strains 75-3, XV56, and XG101 were characterized by their protein profiles by one-dimensional electrophoretic separation $(3,25)$. Extracts of whole cell proteins were obtained from $2 \mathrm{ml}$ of bacterial suspension $\left(5 \times 10^{8}\right.$ $\mathrm{CFU} / \mathrm{ml}, A_{600}=0.3$ ). The pellet was suspended in $200 \mu \mathrm{l}$ of lysis buffer $(51.4 \mathrm{mM}$ Tris-HCl, $\mathrm{pH} 6.8,1.67 \%$ SDS, $10 \%$ 2mercaptoethanol, $16.7 \%$ glycerol, $0.01 \%$ bromophenol blue) and the suspension heated at $100^{\circ} \mathrm{C}$ for $10 \mathrm{~min}$ and centrifuged at $16,000 \times g$ for $10 \mathrm{~min}$. Protein samples of $12.5 \mu \mathrm{l}$ were loaded onto a discontinuous gel consisting of a stacking gel $(5 \%$ total acrylamide, $62 \mathrm{mM}$ Tris- $\mathrm{HCl}, \mathrm{pH} 8.9$, $0.05 \%$ SDS ) and a separation gel (10\% total acrylamide, $378 \mathrm{mM}$ Tris- $\mathrm{HCl}, \mathrm{pH}$ 6.8, $0.05 \%$ SDS). Solutions were deaerated for $15 \mathrm{~min}$ and polymerized by adding $0.03 \%$ of ammonium persulfate and $0.001 \%$ of tetramethylethylenediamine (Temed). Electrophoresis was performed at $4^{\circ} \mathrm{C}$ by using a Protean II double slab vertical electrophoresis apparatus (Bio-Rad Laboratories) filled with electrophoresis buffer $(52 \mathrm{mM}$ Tris, $53 \mathrm{mM}$ glycine, $\mathrm{pH}$ 8.9, 0.1\% SDS). The voltage was $100 \mathrm{~V}$ until the samples reached the separation gel and increased to $180 \mathrm{~V}$ until the end of running. The gel was silver stained at room temperature (3).

Sequencing of the 16S rRNA gene and the intergenic spacer. The $16 \mathrm{~S}$ rRNA gene and the intergenic spacer (IGS) between the $16 \mathrm{~S}$ and the 23S rRNA genes of strains CNPH345, CNPH411, CNPH467, and CNPH496 were amplified using primers FGPS6-63 and FGPL132'-38 and sequenced using the HAB1-6 primers (16). Amplification was performed in a final volume reaction of $25 \mu \mathrm{l}$ using $50 \mathrm{ng}$ of DNA, $0.4 \mathrm{mM}$ each primer, $200 \mu \mathrm{M}$ dNTPs, $1 \mathrm{U}$ of ThermalAce DNA polymerase (Invitrogen Life Technologies), and $1 \times$ ThermalAce buffer. Amplification conditions consisted of one cycle of $95^{\circ} \mathrm{C}$ for $2 \mathrm{~min} ; 30$ cycles of $95^{\circ} \mathrm{C}$ for $30 \mathrm{~s}, 60^{\circ} \mathrm{C}$ for $30 \mathrm{~s}$, and $72^{\circ} \mathrm{C}$ for $2 \mathrm{~min}$; followed by a final cycle of $72^{\circ} \mathrm{C}$ for $4 \mathrm{~min}$. PCR products were gel purified with a GFX PCR purification kit (Amersham Biosciences, Piscataway, NJ) and sequenced in an $\mathrm{ABI}$ 377 sequencing machine (Applied Biosystems, Foster, CA) using the DYEnamic ET terminator cycle sequencing kit (Amersham Biosciences) according to the manufacturer's protocols. PCR products were sequenced to a minimum of a $2 \times$ coverage.

Sequences were assembled using Sequencher V 3.1 (GeneCodes, Ann Arbor, MI) and edited when necessary based on a visual inspection of the chromatograms. Consensus sequences from each strain were compared with sequences of strains Xv1111 (X. vesicatoria), XV153 (X. axonopodis pv. vesicatoria), and XCGA2 (X. gardneri) deposited in GenBank (accession numbers AF123088, AF123089, and AF 123093) (15) using Clustal W (28).
Strains XV153 and XCGA2 are other designations for the original strains 75-3 and XG101, respectively (16). Sequence divergences were estimated with the Kimura two-parameter model with a 3:1 transition:transversion ratio (16) using the DNADIST routine of PHYLIP, version $3.6 a 3$ (10). Parsimony analyses were done as described above except that the DNAPARS routine was used.

\section{RESULTS}

PFGE analysis. Six haplotypes represented by strains CNPH345, CNPH411,
CNPH467, CNPH468, CNPH485, and CNPH496 were distinguished among the 215 strains based on their $\mathrm{Xba \textrm {I }}$ restriction patterns (Fig. 1). These haplotypes and those of reference strains 75-3, XV56, and XG101 were further clustered into three PFGE groups by the parsimony analysis (Fig. 2). The first group was represented by strains $75-3$, CNPH411, CNPH468, and CNPH485, with coefficients of similarity ranging from 86 to $93 \%$. The second group was represented by strains XV56 and CNPH345, which shared only $46 \%$ similarity. The third group comprised strains

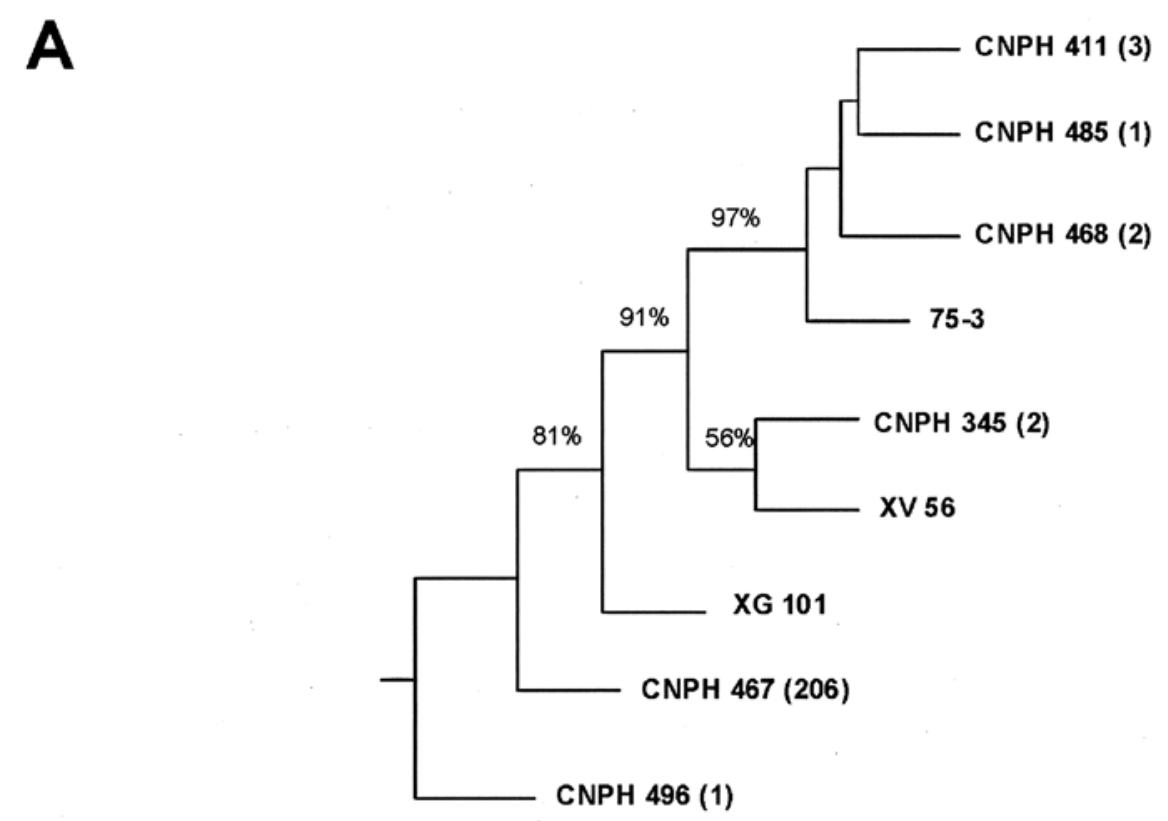

B

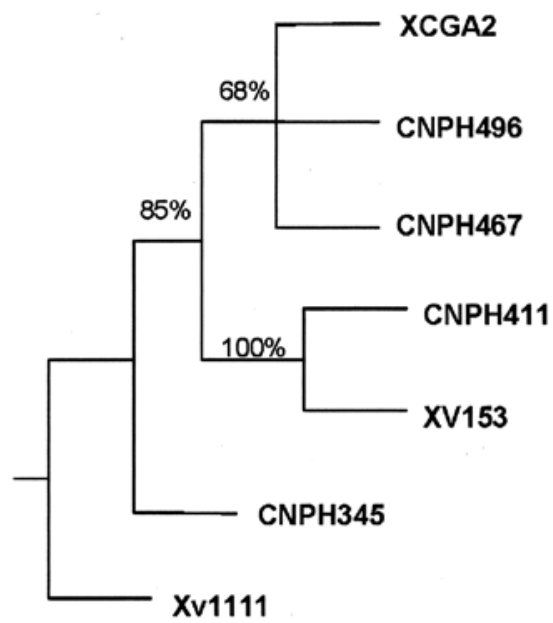

Fig. 2. Genetic relationships among strains representative of pulsed-field gel electrophoresis (PFGE) haplotypes of Xanthomonas spp. associated with tomato bacterial spot based on parsimony analysis of $\mathbf{A}$, PFGE data, and $\mathbf{B}$, sequence of 16S rRNA and intergenic sequence. A, Numbers of strains of each haplotype are in parenthesis. B, Strains XV153 and XCGA2 are other designations of the original strains 75-3 and XG101, respectively (16). Bootstrap values above 50\% are depicted at the corresponding nodes. 
XG101, CNPH467, and CNPH496, with coefficients of similarity ranging from 64 to $91 \%$.

Phenotypic characterization. The phenotypic features were rather uniform among strains belonging to the same PFGE group (Table 2). None of the strains from PFGE group 1, for instance, was able to pathogenic on tomato and pepper, causing brown spots with raised borders and sunken centers. Furthermore, in addition to strain 75-3, three strains from this group were characterized by protein profiles and four by carbon source utilization. All of these strains contained the characteristic $\alpha$ protein (3) of $32 \mathrm{kDa}$ and were able to use gentiobiose, maltose, and $\mathrm{D}(+)$ trehalose. However, they were unable to use $\mathrm{D}(+)$ melezitose differently from strain 75-3 and differed in their ability to use $\mathrm{D}(+)$ melezitose and $\mathrm{D}(+)$ raffinose. Strains of PFGE group 2, on the other hand, showed amylolytic and pectolytic activity and were characterized by the presence of the $\beta$ protein (3) of $27 \mathrm{kDa}$. They were pathogenic only on tomato, causing dark brown hydrolyze starch and pectate, but all were

and flat spots surrounded by water-soaked areas. Strains XV56 and CNPH345 of this group utilized gentiobiose, maltose, and $\mathrm{D}(+)$ trehalose, as in PFGE group 1. Both strains also utilized $\mathrm{D}(+)$ raffinose, but only strain CNPH345 utilized $\mathrm{D}(+)$ melezitose. PFGE group 3 strains, like the PFGE group 1 strains, were unable to hydrolyze starch or pectate. Most of them were pathogenic on both tomato and pepper, whereas $14 \%$ were pathogenic only on tomato. The symptoms on this host were the same as those caused by strains of PFGE group 2. When 22 group 3 strains were characterized by protein profile and carbon source utilization, 18 reacted similarly to the reference strain XG101. They were characterized by the presence of the $\beta$ protein as well as the inability to use gentiobiose, maltose, and $\mathrm{D}(+)$ melezitose and the ability to use $\mathrm{D}(+)$ trehalose. The utilization of $\mathrm{D}(+)$ raffinose was variable.

rRNA sequence analysis. The sequences of the 16S rRNA gene and the IGS region were determined for strains CNPH345, CNPH411, CNPH467, and CNPH496 (GenBank accession numbers

Table 2. Phenotypic features of strains from the central-west Brazil within pulsed-field gel electrophoresis (PFGE) groups ${ }^{\mathrm{a}}$

\begin{tabular}{lccc}
\hline Features & PFGE group 1 & PFGE group 2 & PFGE group 3 \\
\hline Amilolytic activity & 0 & 100 & 0 \\
Pectolytic activity & 0 & 100 & 0 \\
Specific protein $^{\mathrm{b}}$ & $\alpha$ & $\beta$ & $\beta$ \\
Carbon source $^{\text {Gentiobiose }}$ & 100 & 100 & 0 \\
Maltose & 100 & 100 & 0 \\
D(+) melezitoze & 0 & 100 & 0 \\
D(+) raffinose & 75 & 100 & 21 \\
D(+) trehalose & 100 & 100 & 100 \\
Pathogenicity & & & 100 \\
Tomato cv. Walter & 100 & 100 & 86 \\
Pepper cv. Early Calwonder & 100 & 0 & \\
\hline
\end{tabular}

${ }^{a}$ Percent of strains in the group that was characterized by positive results in the respective test.

${ }^{\mathrm{b}}$ Specific protein band in sodium dodecyl sulfate-polyacrylamide gel electrophoresis.

Table 3. Frequency of Xanthomonas spp. isolated from processing tomato fields in central-west Brazil

\begin{tabular}{|c|c|c|c|}
\hline \multirow[b]{2}{*}{ State, county and year, field number } & \multicolumn{3}{|c|}{ Frequency of Xanthomonas spp. $(\%)^{\mathrm{a}}$} \\
\hline & XG & XAV & $\mathbf{X V}$ \\
\hline \multicolumn{4}{|l|}{ Goiás } \\
\hline \multicolumn{4}{|l|}{ Itapaci, 1997} \\
\hline 1 & 100.0 & 0.0 & 0.0 \\
\hline 2 & 100.0 & 0.0 & 0.0 \\
\hline 3 & 50.0 & 0.0 & 50.0 \\
\hline \multicolumn{4}{|l|}{ Rio Verde, 1997} \\
\hline 1 & 100.0 & 0.0 & 0.0 \\
\hline 2 & 100.0 & 0.0 & 0.0 \\
\hline \multicolumn{4}{|l|}{ Morrinhos, 1998} \\
\hline 1 & 94.9 & 5.1 & 0.0 \\
\hline $2^{b}$ & 66.7 & 33.3 & 0.0 \\
\hline 2 & 95.0 & 5.0 & 0.0 \\
\hline 3 & 75.0 & 25.0 & 0.0 \\
\hline \multicolumn{4}{|l|}{ Morrinhos, 2000} \\
\hline 1 & 100.0 & 0.0 & 0.0 \\
\hline \multicolumn{4}{|l|}{ Minas Gerais } \\
\hline \multicolumn{4}{|l|}{ Patos de Minas, 1998} \\
\hline 1 & 100.0 & 0.0 & 0.0 \\
\hline
\end{tabular}

${ }^{\mathrm{a}} \mathrm{XG}=$ Xanthomonas gardneri, $\mathrm{XAV}=\mathrm{X}$. axonopodis pv. vesicatoria, $\mathrm{XV}=X$. vesicatoria.

${ }^{\mathrm{b}}$ Samples collected at seedling stage.
AY288080, AY288081, AY288082, and AY288083, respectively) and compared with those of reference strains. The genetic distances $(d)$ between strains CNPH411 and XV153 (X. axonopodis pv. vesicatoria) and among strains CNPH496, CNPH467, and XCGA2 (X. gardneri) were 0.0000 , whereas strain CNPH345 was most closely related to Xv1111 $(X$. vesicatoria; $d=0.0010)$. The parsimony clustering agreed with the genetic distance data; strains CNPH496 and CNPH467 clustered with XG101, CNPH411 clustered with 75-3, and CNPH345 with Xv1111 (Fig. 2).

Classification and haplotypic frequency. Based on the phenotypic and genotypic traits presented above, strains CNPH496 and CNPH467 were classified as $X$. gardneri, strain $\mathrm{CNPH} 411$ as $X$. axonopodis pv. vesicatoria, and $\mathrm{CNPH} 345$ as $X$. vesicatoria. Based on these species assignments, $X$. gardneri was the most prevalent species recovered from all 10 fields; in 6 fields, it was the only species identified (Table 1). Of the two X. gardneri haplotypes, the one represented by strain CNPH467 was by far the most prevalent (206 of 207 cases). This strain was deposited in the culture collection of the Instituto Biológico (Campinas, Brazil) under IBSBF No. 1782.

\section{DISCUSSION}

Genotypic and phenotypic approaches were used to assign strains of xanthomonads causing bacterial spot disease on processing tomato in central-west Brazil to established Xanthomonas spp. Based on PFGE analysis and ribosomal RNA sequence analysis, two haplotypes were identified as $X$. gardneri. This classification is strengthened by the fact that, like reference strain XG101, all strains were not able to use $\mathrm{D}(+)$ melezitose but used $\mathrm{D}(+)$ trehalose (8). Finally, the finding that the Brazilian strains were unable to use gentiobiose agrees with an earlier report on $X$. gardneri strains in Costa Rica (5). Among the carbon sources utilized, gentiobiose and maltose were the most discriminatory, with negative results only for strains of $X$. gardneri. The substrate maltose might have diagnostic value, but more strains representing all phenotypic groups of $X$. axonopodis pv. vesicatoria ( $\mathrm{A}, \mathrm{A} 1$, and $\mathrm{C} ; 16$ ), and $X$. vesicatoria should be evaluated.

Members of $X$. gardneri were pathogenic on either tomato and pepper or only on tomato. It is still unknown if the host range observed for $X$. gardneri also is determined by the avirulence genes $\operatorname{avrBs} T$, which induces hypersensitive response in all pepper lines (20), as for both $X$. axonopodis pv. vesicatoria and $X$. vesicatoria. On artificially inoculated tomato leaves, $X$. gardneri caused symptoms similar to those described for $X$. vesicatoria (3). 
The predominant recovery of $X$. gardneri strains from tomato fields reported here may be indicative that this species is becoming an important component of the bacterial spot complex and is no longer as rare in nature as reported (15). Epidemics caused by $X$. gardneri never have been reported before. The occurrence of new species and types of xanthomonads causing bacterial spot on processing tomato in Brazil may be a consequence of the gradual substitution of open-pollinated cultivars, either locally bred or imported from California, by hybrids marketed by international seed companies (1). Contaminated seed seem to be a crucial factor for introducing the pathogen into noninfested areas $(2,11,17)$. Symptoms on seedlings commercially grown in greenhouses, as observed in Morrinhos in 1998 in field 2, indicated that infected seed might have been used. It was the first year of tomato cropping on that farm and, despite the introduction of intensive copper spraying, the disease became widespread. It is intriguing that the frequency of $X$. axonopodis pv. vesicatoria strains declined over time while the frequency of $X$. gardneri increased (Table 3 ). It could be speculated that differences in fitness, as has been demonstrated in $X$. axonopodis pv. vesicatoria with tomato race 3 in relation to race 1 (16), also could exist between $X$. axonopodis pv. vesicatoria and $X$. gardneri.

This is the first survey of xanthomonads on processing tomato in Brazil; therefore, it cannot be stated whether or not outbreaks caused by $X$. gardneri are recent. The low polymorphism found among strains could be an indication of a recent introduction event. However, this hypothesis is still tentative, because the level of genetic variation within $X$. gardneri stills needs to be assessed. Thus, understanding bacterial spot complex in Brazil is the first step for directing future research on detection, survival, chemical control efficiency, and breeding for attaining acceptable levels of control in the field.

\section{ACKNOWLEDGMENTS}

We thank R. Sant'ana from Arisco and L. C. Rodrigues from Olé Alimentos for their help in arranging field surveys, F. Carvalho and N. Wulff for technical assistance, and C. A. Lopes and J. B. Jones for suggestions and revision of the manuscript.

\section{LITERATURE CITED}

1. Barbosa, V. 1997. The processing tomato growing system under tropical and subtropical conditions-The Brazilian experience. Pages 94-97 in: Proc. Int. Conf. Processing Tomato, 1st, Recife.

2. Bashan, Y., and Okon, Y. 1986. Internal and external infections of fruits and seeds of pep- pers by Xanthomonas campestris pv. vesicatoria. Can. J. Plant Pathol. 64:2865-2871.

3. Bouzar, H., Jones, J. B., Minsavage, G. V., Stall, R. E., and Scott, J. W. 1994. Proteins unique to phenotypically distinct groups of Xanthomonas campestris pv. vesicatoria revealed by silver staining. Phytopathology $84: 39-44$.

4. Bouzar, H., Jones, J. B., Stall, R. E., Hodge, N. C., Minsavage, G. V., Benedict, A. A., and Alvarez, A. M. 1994. Physiological, chemical, serological, and pathogenic analyses of a worldwide collection of Xanthomonas campestris $\mathrm{pv}$. vesicatoria strains. Phytopathology 84:663-667.

5. Bouzar, H., Jones, J. B., Stall, R. E., Louws, F. J., Schneider, M., Rademaker, J. L. W., de Bruijn, F. J., and Jackson, L. E. 1999. Multiphasic analysis of xanthomonads causing bacterial spot disease on tomato and pepper in the Caribbean and Central America: evidence for common lineages within and between countries. Phytopathology 89:328-335.

6. Cuppels, D., and Kelman, A. 1974. Evaluation of selective media for isolation of soft-rot bacteria from soil and plant tissue. Phytopathology 64:468-475.

7. De Ley, J. 1978. Modern molecular methods in bacterial taxonomy: evaluation, application, prospects. Pages 347-357 in: Proc. Int. Conf. Plant Pathol. Bacteria, 4th, Angers, France.

8. Dye, D. W. 1966. Cultural and biochemical reaction of additional Xanthomonas species. N. Z. J. Sci. 9:913-919.

9. Egel, D. S., Graham, J. H., and Stall, R. E. 1991. Genomic relatedness of Xanthomonas campestris strains causing diseases on citrus. Appl. Environ. Microbiol. 57:2724-2730.

10. Felsenstein, J. 1995. PHYLIP (Phylogeny Inference Package) version 3.57c. Department of Genetics, University of Washington, Seattle.

11. Gitaitis, R., McCarter, S., and Jones, J. B. 1992. Disease control in tomato transplants produced in Georgia and Florida. Plant Dis. 76:651-656.

12. Goode, M. J., and Sasser, M. 1980. Prevention-The key to controlling bacterial spot and bacterial speck of tomato. Plant Dis. 64:831834.

13. Hildebrand, D. C., Palleroni, N. J., and Schroth, M. N. 1990. Deoxyribonucleic acid relatedness of 24 xanthomonad strains representing 23 Xanthomonas campestris pathovars and Xanthomonas fragariae. J. Appl. Bacteriol. 68:263-269.

14. Jones, A. L., and Geider, K. 2001 Gram-negative bacteria. Erwinia amylovora group. Pages 40-55 in: Laboratory Guide for Identification of Plant Pathogenic Bacteria. N. W. Schaad, J. B. Jones, and W. Chun, eds. American Phytopathological Society, St. Paul, MN.

15. Jones, J. B. 1991. Bacterial spot. Page 27 in: Compendium of Tomato Diseases. J. B. Jones, J. P. Jones, R. E. Stall, and T. A. Zitter, eds. American Phytopathological Society, St. Paul, $\mathrm{MN}$.

16. Jones, J. B., Bouzar, H., Stall, R. E., Almira, E. C., Roberts, P. D., Bowen, B. W., Sudberry, P. M., Strickler, P. M., and Chun, J. 2000. Systematic analysis of xanthomonads (Xanthomonas spp.) associated with pepper and tomato lesions. Int. J. Syst. Evol. Microbiol. 50:1211-1219.

17. Jones, J. B., Stall, R. E., and Bouzar, H. 1998. Diversity among xanthomonads pathogenic on pepper and tomato. Annu. Rev. Phytopathol. 36:41-58

18. Leite, R. P., Jr., Jones, J. B., Somodi, G. C., Minsavage, G. V., and Stall, R. E. 1995. Detection of Xanthomonas campestris pv. Vesicatoria associated with pepper and tomato seed by DNA amplification. Plant Dis. 79:917-922.

19. Leite, R. P., Jr., Minsavage, G. V., Bonas, U., and Stall, R. E. 1994. Detection and identification of phytopathogenic Xanthomonas strains by amplification of DNA sequences related to the hrp genes of Xanthomonas campestris pv. vesicatoria. Appl. Environ. Microbiol. 60:1068-1077.

20. Louws, F. J., Fulbright, D. W., Stephens, C. T., and de Bruijn F. J. 1995. Differentiation of genomic structure by rep-PCR fingerprinting to rapidly classify Xanthomonas campestris pv. vesicatoria. Phytopathology 85:528-536.

21. Minsavage, G. V., Dahlbeck, D., Whalen, M. C., Kearney, B., Bonas, U., Staskawicz, B. J. and Stall, R. E. 1990. Gene-for-gene relationships specifying disease resistance in Xanthomonas campestris pv. vesicatoria-pepper interactions. Mol. Plant-Microbe Interact. 3:41-53.

22. Moore, L. W., Bouzar, H., and Burr, T. 2001. Gram-negative bacteria. Agrobacterium. Pages 17-35 in: Laboratory Guide for Identification of Plant Pathogenic Bacteria. N. W. Schaad, J. B. Jones, and W. Chun, eds. American Phytopathological Society, St. Paul, MN

23. O'Garro, L. W. 1998. Bacterial spot of tomato and pepper on four East Caribbean islands: Races, their abundance, distribution, aggressiveness, and prospects for control. Plant Dis. 82:864-870.

24. Schaad, N. W. 2001. Initial identification of common genera. Pages 1-15 in: Laboratory Guide for Identification of Plant Pathogenic Bacteria. N. W. Schaad, J. B. Jones, and W. Chun, eds. American Phytopathological Society, St. Paul, MN.

25. Silva, J. B. C., and Giordano, L. de B. 1999 Produção mundial e nacional. Pages $8-11$ in: Tomate para Processamento Industrial. J. B. C. Silva and L. de B. Giordano, eds. Embrapa Comunicação para Transferência de Tecnologia, Brasília, Brazil

26. Stall, R. E., Beaulieu, C., Egel, D., Hodge, N. C., Leite, R. P., Minsavage, G. V., Bouzar, H., Jones, J. B., Alvarez, A. M., and Benedict, A. A. 1994. Two genetically diverse groups of strains are included in Xanthomonas campestris pv. vesicatoria. Int. J. Syst. Bacteriol. 44:47-53.

27. Šutic, D. 1957. Bakterioze Crvenog Patlidžana. [Tomato bacteriosis]-Posebna Izd. Inst. Zasht. Bilja, Beograd [Spec. Ed. Inst. Plant Prot., Beograd] 6. Ver. Appl. Mycol 36:734-735.

28. Thompson, J. D., Higgins, D. G., and Gibson, T. J. 1994. CLUSTAL W: improving the sensitivity of progressive multiple sequence alignment through sequence weighting, position specific gap penalties and weight matrix choice. Nucleic Acids Res. 22:4673-4680.

29. Vauterin, L., Hoste, B., Kersters, K., and Swings, J. 1995. Reclassification of Xanthomonas. Int. J. Syst. Bacteriol. 45:472-489.

30. Young, J. M., Saddler, G. S., Takikawa, U., DeBoer, S. H., Vauterin, L., Gardan, L., Gvozdyak, R. I., and Stead, D. E. 1996. Names of plant pathogenic bacteria 1864-1995. Rev. Plant Pathol. 75:721-763. 